\title{
Kowanin, Suatu Santon dari Kulit Batang Garcinia cowa Roxb
}

\author{
Darwati $^{1^{*}}$, Husen H. Bahti ${ }^{1)}$, Supriyatna ${ }^{2)}$, dan Dachriyanus ${ }^{3)}$ \\ 1) Jurusan Kimia, Fakultas Matematika dan Ilmu Pengetahuan Alam \\ Universitas Padjadjaran, Jatinangor, Sumedang. \\ 2)Fakultas Farmasi, Universitas Padjadjaran, Jatinangor, Sumedang. \\ 3) Jurusan Farmasi, Fakultas Matematika dan Ilmu Pengetahuan Alam \\ Universitas Andalas, Limau Manis, Padang.
}

Diterima 08-06-2008

Disetujui 09-02-2009

\begin{abstract}
The compound tetraoxygenated xanthone was isolated from the crude extract of the stem bark of Garcinia cowa Roxb. The compound tetraoxygenated xanthone was caried out as yellow crystal with melting point $136-137^{\circ} \mathrm{C}$. The structure of this compound was detremined base on spectroscopic methods, including UV, IR, 'H-NMR, ${ }^{13} \mathrm{C}-\mathrm{NMR} 1 \mathrm{D}$ and 2D. The compound was found to exhibit cytotoxicity against T47D cell by SRB method
\end{abstract}

Keywords: cowanin, tetraoxygenated xanthone, Garcinia cowa Roxb., T47D, SRB

\section{PENDAHULUAN}

Garcinia cowa Roxb (Guttiferae, Claciaceae), secara umum dikenal dengan nama manggis hutan atau kandis di daerah Sumatera Barat dan cha muang (Thailand). Buahnya dapat dimakan sebagai manisan atau penyedap masakan atau rempah-rempah (Heyne 1987). Daun dan buah telah digunakan untuk memperlancar peredaran darah, pengencer dahak pada batuk filek (Panthong et al, 2006) dan tonikum (Poomipamorn et al, 1997), kulit batang telah digunakan secara tradisional sebagai antiperitik ( $\mathrm{Na}$ Pattalung et al, 1994). Mahabusarakam et al, (2005), telah berhasil mengisolasi senyawa kowa garsinon $A-E$, mangostin dan fuskasanton $A$ dari getah $G$. cowa Tumbuhan ini banyak ditemukan di daerah hutan tropis seperti Malaysia, Thailand dan Indonesia (Burkill 1966). Berdasarkan hasil penelitian spesies ini mengandung golongan santon, benzofenon dan flavonoid. Golongan senyawa ini diketahui memiliki berbagai aktivitas seperti antimikroba, antimalaria, antioksidan, antiimflamasi, antitumor, dan antikanker (Komguem et al, 2005). Dachriyanus et al, (2004), telah berhasil mengisolasi senyawa rubrasanton (aktivitas antioksidan) dan tetrapreniltoluquinon (aktivitas antikanker) dari kulit batang $\mathrm{G}$. cowa. Na Pattalung et al, (1994), melaporkan senyawa kowanol, kowasanton

*Telp: 085222972529

Email: darwati@yahoo.co.id dan norkowanin dengan aktivitas antibakteri dan Panthong et al, 2006, berhasil mengisolasi 14 senyawa diantaranya â-mangostin, kowasanton A-E, kowanin dengan aktivitas antibakteri. Dalam makalah ini akan disampaikan penemuan suatu senyawa santon jenis santon tetraoksigenasi yaitu kowanin dari ekstrak $n-$ heksan kulit batang $G$ cowa. Struktur molekul senyawa tersebut ditetapkan berdasarkan data spektroskopi UV, IR, ${ }^{1} \mathrm{H}$-NMR, ${ }^{13} \mathrm{C}-\mathrm{NMR}, \mathrm{HMQC}$ dan HMBC serta didukung oleh perbandingan data sejenis yang telah dilaporkan sebelumnya. Aktivitas anti kanker juga telah dilakukan terhadap sel T47D dengan metode SRB.

\section{BAHAN DAN METODE}

Bahan penelitian. Serbuk kulit batang tumbuhan Garcinia cowa Roxb. diperoleh dari Hutan Sarasahbonta Payakumbuh Sumatera Barat pada bulan April 2006.

Bahan kimia. Metanol, $n$-heksan, etilasetat, aseton, kloroform, akuades, pelat silika gel $\mathrm{GF}_{254}$, silikagel $\mathrm{GF}_{60}, \mathrm{GF}_{254}$, pereaksi serium sulfat. Bahanbahan kimia yang digunakan untuk keperluan ekstraksi adalah berkulitas teknis dan sudah didestilasi sedangkan untuk keperluan analisis dan pemurnian digunakan bahan yang berkualitas pro analisis (p.a).

Alat penelitian. Seperangkat alat kromatografi kolom cair vakum, destilasi, penguap putar, bejana lapis tipis, dan alat-alat gelas yang biasa digunakan di laboratorium. 
Alat-alat yang digunakan untuk identifikasi adalah Fisher-Johns melting point apparatus, spektrofotometer UV-VIS Beckman DU-7500, FT-IR 8400 Shimadzu, ${ }^{1} \mathrm{H}$, ${ }^{13} \mathrm{C}-\mathrm{RMI}$ JEOL JNM A-500.

Cara kerja. Cuplikan tanaman yang berupa kulit batang $G$ cowa dibersihkan dari pengotornya, kemudian dikeringkan di bawah sinar matahari. Setelah itu dipotong-potong dan dihaluskan hingga berbentuk serbuk.

Ekstraksi dan isolasi senyawa santon. Serbuk kulit batang $\mathrm{G}$. cowa sebanyak $2 \mathrm{~kg}$ dimaserasi berturutturut menggunakan pelarut $n$-heksan, diklorometan dan metanol masing-masing selama $3 \times 24$ jam pada suhu kamar, sehingga diperoleh masing-masing ekstrak kasar $n$-heksan $(30 \mathrm{~g})$, diklorometan $(100 \mathrm{~g})$, dan metanol (300 g) . Kemudian terhadap ekstrak $n$-heksan dipisahkan antara filtrat dan residunya. Ekstrak $n$ heksan yang diperoleh disaring dan diuapkan dengan penguap putar sehingga diperoleh ekstrak kental. Selanjutnya terhadap ekstrak kental (10 g) dilakukan pemisahan dan pemurnian dengan berbagai teknik kromatografi meliputi kromatografi cair vakum (KCV), kromatografi kolom grafitasi (KKG). Terhadap ekstrak kasar $n$-heksan $(2 \mathrm{~g})$ dilakukan pemisahan dengan $\mathrm{KCV}$ dengan menggunakan silika gel $\mathrm{GF}_{254} 20 \mathrm{~g}$ sebagai adsorben dan eluen campuran $n$-heksan-EtOAc $9: 1$, $8: 2,7: 3,6: 4$, dan EtOAc. Sehingga diperoleh 5 fraksi A1-A5. Selanjutnya terhadap fraksi A2 dipisahkan kembali dengan kromatografi kolom grafitasi dengan silika gel $\mathrm{GF}_{60}$ dengan menggunakan eluen yang sama sehingga diperoleh 4 fraksi B1-B4. Terhadap fraksi B2 dilakukan pemurnian sampai diperoleh senyawa 1 yang diidentifikasi sebagai kowanin $(8 \mathrm{mg})$.

Uji aktivitas antikanker terhadap sel T47D. Sel yang telah siap uji sebanyak $190 \mu \mathrm{L}$ ditambah dengan sampel uji sebanyak $10 \mu \mathrm{L}$ (variasi konsentrasi 20; 10; $5 ; 2,5 ; 1,15 ; 0,63 ; 0,31 ;$ dan $0,16 \mu \mathrm{g} / \mathrm{mL})$. Selanjutnya diinkubasi selama $3-4$ hari pada suhu $37^{\circ} \mathrm{C}$. Setelah itu sel difiksasi dengan TCA 50\%. Pewarnaan dilakukan menggunakan SRB 0,4\% dalam asam asetat $1 \%$ selama 30 menit. Warna SRB yang tidak terikat dibilas dengan asam asetat $1 \%$ sedangkan yang terikat diekstraksi dengan basa tris ( $\mathrm{pH} 10)$. Intensitas warna yang dihasilkan diukur dengan menggunakan ELISA plate readerpada $\lambda_{\text {maks }} 515 \mathrm{~nm}$. Persen viabilitas dihitung berdasarkan persamaan sebagai berikut.
$\%$ Viability s $=\frac{A 1-A 0}{A 2-A 0} \times 100 \%$

$\mathrm{A} 0=$ Absorban blanko

A1 = Absorban (sel + sampel)

$\mathrm{A} 2=$ Absorban control (sel $+10 \%$ DMSO)

$\%$ inhibisi $=1-\%$ viabilita $\mathrm{s}$

Nilai $I_{50}$ dihitung dengan cara analisis regresi linear antara persen viabilitas dan konsentrasi (Skehan et al, 1990).

\section{HASIL DAN PEMBAHASAN}

Senyawa 1 (kowanin). Diperoleh berupa kristal amorf kuning sebanyak $8 \mathrm{mg}$ dari ekstrak kasar $2 \mathrm{~g}$ dengan titik leleh $136^{\circ} \mathrm{C}-137^{\circ} \mathrm{C}$. UV $(\mathrm{MeOH}) \ddot{\mathrm{e}}_{\text {max }}(\log \mathrm{a})$ nm : 203 (5,62), $243(5,54), 258(5,45)$, dan $315(5,38)$ Efek batokromik dengan penambahan $\mathrm{NaOH}$ memperlihatkan serapan maksimum pada $\ddot{e}_{\text {max }}(\mathrm{MeOH})$ (log å) nm: 205 (6,01), 243 (5,50), 267 (5,30), dan 368 $(5,54)$. IR $(\mathrm{KBr})^{{ }_{\text {max }}} \mathrm{cm}^{-1} \quad 3421,2966,2920,2854$, 1643, 1608, 1581 dan 1080. ${ }^{1} \mathrm{H}-\mathrm{NMR}\left(\mathrm{CDCl}_{3}\right)$, dan ${ }^{13} \mathrm{C}-$ $\operatorname{NMR}\left(\mathrm{CDCl}_{3}\right)$.

Senyawa 1 berupa kristal berwarna kuning dengan titik leleh $136^{\circ}-137^{\circ} \mathrm{C}$. Spektrum UV $(\mathrm{MeOH})$ menunjukkan serapan maksimum pada $\lambda_{\text {maks }}(\log$ å) $\mathrm{nm}$ : $203(5,62), 243(5,54), 258(5,45)$, dan $315(5,38)$ yang karakteristik untuk tetraoksigenasi santon dan mengalami pergeseran batokromik pada penambahan pereaksi geser $\mathrm{NaOH}$ dengan $\lambda_{\text {maks }}$ (log å) nm: 205 $(6,01), 243(5,50), 267(5,30)$, dan $368(5,54)$ (Gambar 1).

Spektrum IR memperlihatkan adanya pita-pita serapan $\left(v_{\text {maks }} \mathrm{cm}^{-1}\right)$ untuk gugus hidroksil (3421), C-H alifatik $(2966,2920)$ karbonil terkelasi $(1643)$, konyugasi dari cincin benzena pada $(1608,1581$, dan 1461) dan C-O eter (1280) (Gambar 2).

Spektrum ${ }^{1} \mathrm{H}$ NMR dan ${ }^{13} \mathrm{C}$ HNMR dari kowanin (1) (Tabel 1) dalam kloroform memperlihatkan sinyal-sinyal yang karakteristik untuk senyawa golongan santon yang terprenilasi. Spektrum ${ }^{1} \mathrm{H}$ NMR (Gambar 3) menunjukkan adanya sinyal untuk gugus hidroksil yang terkhelasi pada $\delta_{H} 13,81(1 \mathrm{H}, s)$ yang ditempatkan pada posisi C1. Tidak adanya sinyal proton aromatik pada daerah 7,40-7,60 menunjukkan bahwa tidak adanya proton peri terhadap gugus karbonil. Dua sinyal proton aromatik 


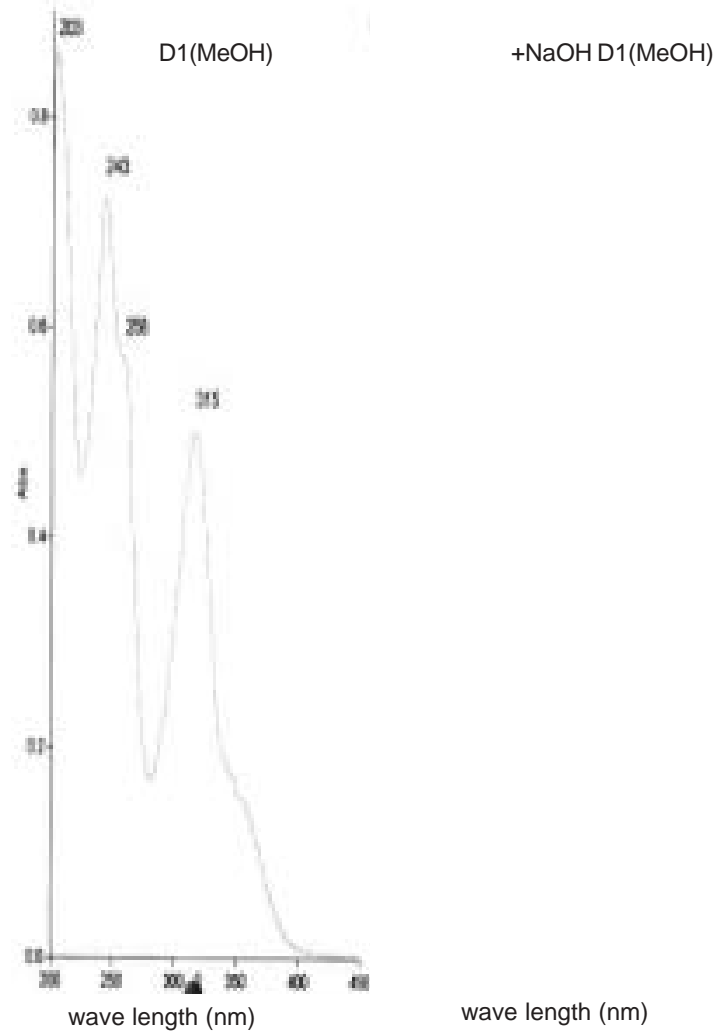

Gambar 4. Spektrum C NMR senyawa 1 (kowanin).

Gambar 1. Spektrum UV senyawa 1 (kowanin).
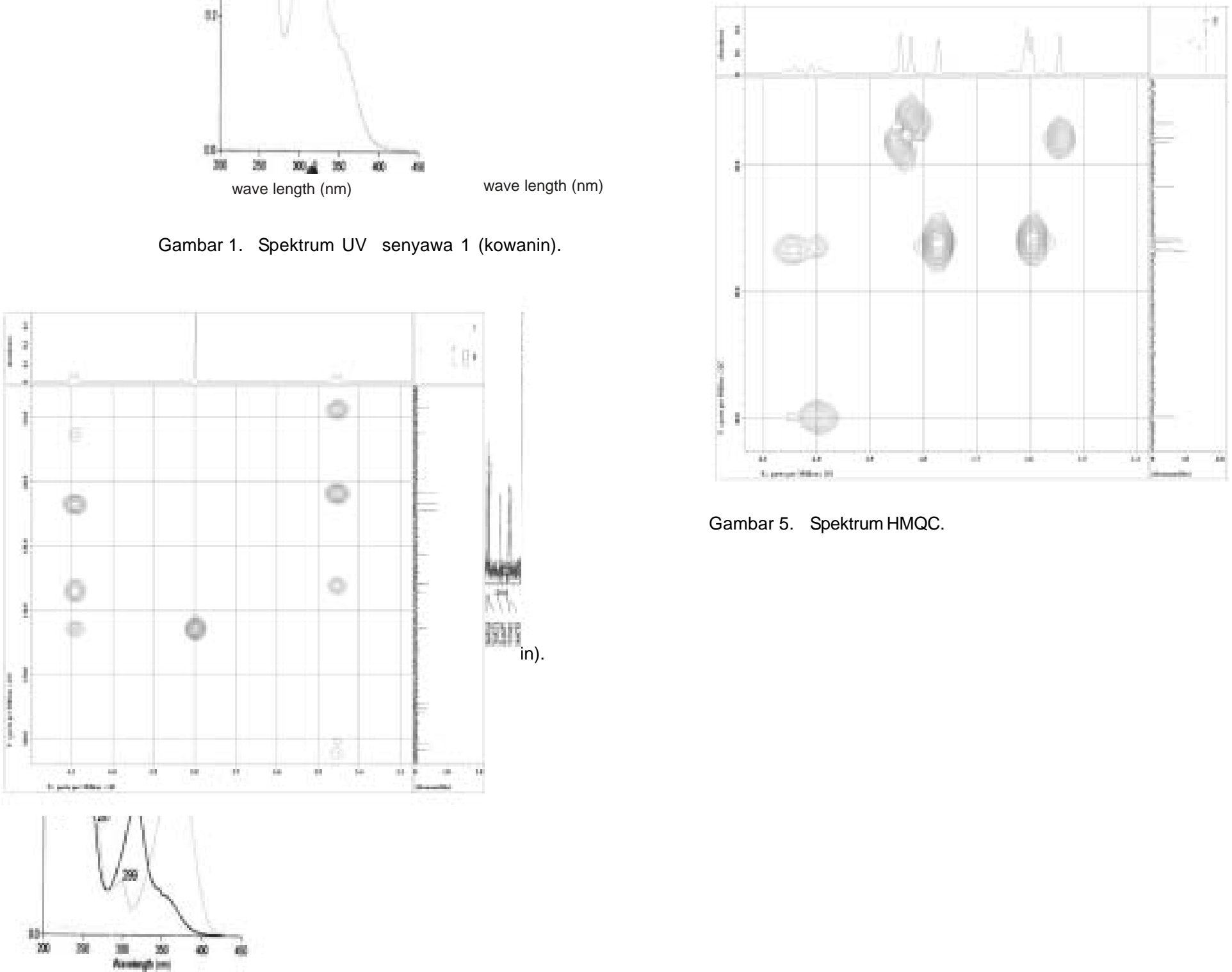

Gambar 5. Spektrum HMQC. 
Tabel 1. Data geseran kimia proton dan karbon dari spektrum ${ }^{1} \mathrm{H}$ dan ${ }^{13} \mathrm{C}$ NMR dan korelasi NMR 2D dari kowanin (1) $500 \mathrm{MHz}$ untuk ${ }^{1} \mathrm{H}$ dan $125 \mathrm{MHz}$ untuk ${ }^{13} \mathrm{C}$ dalam kloroform- $d$.

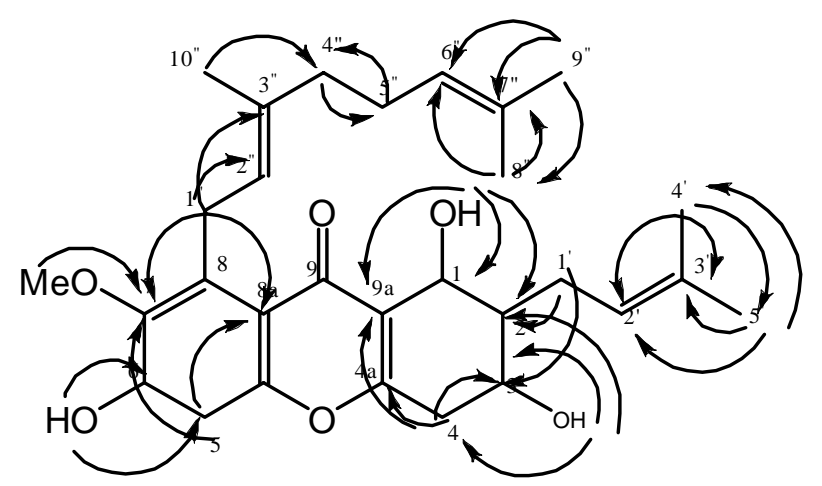

Gambar 7. HMBC senyawa 1.

terlihat pada $\delta_{\mathrm{H}} 6,29(1 \mathrm{H}, s)$, dan $6,83(1 \mathrm{H}, s)$. Pada spektrum $\mathrm{H}$ NMR juga terlihat sinyal-sinyal karakteristik untuk satu unit prenil pada $\delta_{\mathrm{H}} 3,45(2 \mathrm{H}, d, J=7,3)$, $5,02(1 \mathrm{H}, d, J=7,3), 1,59(3 \mathrm{H}, s), 1,54(3 \mathrm{H}, s)$ dan satu unit geraniol pada $\delta_{\mathrm{H}} 4,09(2 \mathrm{H}, d, J=6,1), 5,28$ $(1 \mathrm{H}, t, J=6,1) 1,99(2 \mathrm{H}, \mathrm{t}, \mathrm{J}=\ldots), 2,04(2 \mathrm{H}, \mathrm{m}) 5,26$ $(1 \mathrm{H}, t, J=1,77(1 \mathrm{H}, s) 1,85(3 \mathrm{H}, s)$, dan 1,82 $(3 \mathrm{H}, s)$.<smiles>COC1=C([CH-]/C(C)=C\CCC=C(C)C)c2c(oc3c(c2=O)C(O)C(CC=C(C)C)C(O)C3)CC1O</smiles>

Gambar 8. Struktur molekul senyawa 1 (kowanin).

Selain itu juga terlihat sinyal untuk satu proton metoksi pada $\delta_{\mathrm{H}} 3,83(3 \mathrm{H}, \mathrm{s})$.

Pada spektrum ${ }^{13} \mathrm{C}$ NMR senyawa 1 dalam kloroform terlihat adanya 25 sinyal karbon. Pada pektrum DEPT terlihat adanya enam karbon metil pada $\delta_{\mathrm{C}} 62,26$ (C-OMe), 16,67, 17,86; 18,11; 25,82; dan 26,07, empat karbon metilen pada $\delta_{\mathrm{C}} 21,17,21,63,26,72$; 
dan 39,88 ; lima buah karbon metin pada $\delta_{\mathrm{C}} 93,46$; 101,$07 ; 121,61 ; 123,38$; dan 124,34; dan 14 buah karbon kuaterner pada $\delta_{\mathrm{C}} 160,79 ; 108,58 ; 161,79$; 155,$25 ; 154,67 ; 142,74 ; 135,80 ; 112,42 ; 182,18$ (C karbonil dengan posisi para terhadap gugus hidroksi, dimana sinyal ini khas untuk inti santon), 103,80; 155,95; 131,49; 137,29; dan 136,02.

Berdasarkan analisa data NMR 1 dimensi diketahui senyawa hasil isolasi mempunyai rumus molekul $\mathrm{C}_{29} \mathrm{H}_{34} \mathrm{O}_{6}$ dengan berat molekul 478 , dan nilai $\mathrm{DBE}=1$. Hal ini sesuai dengan data NMR yaitu 9 ikatan rangkap $\mathrm{C}=\mathrm{C}$ (enam diantaranya untuk rangka dasar santon, satu untuk unit prenil dan dua untuk unit geranil), satu karbonil $(\mathrm{C}=\mathrm{O})$ dan tiga cincin dari rangka dasar santon.

Identifikasi sinyal-sinyal karbon lebih lanjut ditetapkan berdasarkan spektrum NMR 2D, HMQC, HMBC. Pada spektrum HMQC (Gambar 5) terlihat proton aromatik pada $\ddot{a}_{H} 6,29$ berikatan langsung dengan $\ddot{a}_{c} 93,46$ dan pada HMBC terlihat bahwa proton ini berkorelasi lewat 3 ikatan dengan karbon pada $\delta_{C}$ 108,58 (C-2), dan 103,80 (C-9a) dan lewat dua ikatan dengan karbon pada ä $_{c} 155,25$ (C- 4a) dan 161,79 (C-3) sehingga proton ini ditempatkan pada posisi C-4. Proton pada $\ddot{a}_{H} 6,83$ pada spektrum $H M Q C$ berikatan langsung dengan karbon pada äc 154,676 dan pada spektrum HMBC terlihat bahwa proton ini berkorelasi dengan karbon pada äc 112,42 (C-8a), dan 142,74 (C-7) dan lewat dua ikatan dengan karbon pada 155,95 (C-10ㄹ), sehingga proton ini ditempatkan pada posisi C-5.

Pada spektrum HMBC (Gambar 6) terlihat proton pada $\ddot{H}_{H} 3,45(\mathrm{H}-11)$ berkorelasi lewat dua ikatan dengan karbon pada äc 108,58 (C-2) dan lewat tiga ikatan dengan karbon pada 161,79 (C-3), sehingga unit prenil ini ditempatkan pada posisi C-2. Proton benzilik pada $4,09(2 \mathrm{H}, \mathrm{d}, \mathrm{J}=6,10$ dari gugus geranil pada spektrum HMBC menunjukkan korelasi dengan karbon pada C8 $(112,4)$, C-17(123,4), C-18 $(137,3)$, C-7 $(142,7)$, sehingga gugus geranil ini ditempatkan pada posisi C8 pada cincin B. Dari spektrum HMQC juga terlihat bahwa proton metil dari gugus metoksi pada $\delta_{\mathrm{H}} 3,82$ terikat pada karbon $\ddot{a}_{c} 62,26$ dan dalam spektrum $\mathrm{HMBC}$ terlihat proton ini berkorelasi lewat tiga ikatan dengan karbon pada $\ddot{a}_{\mathrm{C}} 142,74$ (C-7), sehingga proton metoksil ini ditempatkan pada posisi C-7. Pada spektrum HMBC juga terlihat proton hidroksi pada $\delta_{\mathrm{H}}$ $6.34(2 \mathrm{H}, \mathrm{d}, 7.3)$ berkorelasi lewat tiga ikatan dengan karbon pada $\delta_{\mathrm{C}} 101,7$ (C-5) dan lewat dua ikatan dengan karbon pada $\delta_{C} 154,6$ (C-6) sehingga proton ini ditempatkan pada posisi C-6. Selanjutnya $\mathrm{OH}$ pada $\delta_{\mathrm{H}}$ 13,81 pada spektrum HMBC menunjukkan korelasi dengan karbon pada $\delta_{\mathrm{C}} 103,8$ (C-9⿱⺈) $), 108,6$ (C-2) dan $160,8(\mathrm{C}-1)$. Sinyal untuk proton pada $\delta_{\mathrm{H}} 6,19(1 \mathrm{H}, \mathrm{s})$ pada spektrum HMBC berkorelasi lewat dua ikatan dengan karbon pada 161,8 (C-3) dan lewat tiga ikatan dengan karbon pada 108,6 (C-2) dan 93,5 (C-4), sehingga proton ini ditempatkan pada posisi C-3.

Hubungan antara proton dengan karbon tetangganya yang berjarak 2 ikatan dan 3 ikatan dari spektrum HMBC untuk senyawa 1 dapat dilihat pada Gambar 7.

Dari analisa yang telah dilakukan terhadap spektrum ${ }^{1} \mathrm{H}$ RMI, ${ }^{13} \mathrm{C}$ RMI, COSY, HMQC, dan HMBC dapat disimpulkan bahwa senyawa 1 adalah jenis santon terprenilasi: 1,3,6-trihidroksi-7-dimetoksi-2-bis(3-meil-but-2-enil)-8-(3,7-dimetil-2,6-oktadienil)-santon, dengan rumus molekul $\mathrm{C}_{29} \mathrm{H}_{34} \mathrm{O}_{6}$.

\section{KESIMPULAN}

Kulit batang G. cowa Roxb. telah berhasil diisolasi senyawa santon tretratoksigenasi yang ditetapkan sebagai kowanin dan mempunyai aktivitas antikanker terhadap sel T47 D dengan nilai $\mathrm{Ic}_{50} 10,4 \mu \mathrm{g} / \mathrm{mL}$ dan struktur senyawa seperti Gambar 8.

\section{UCAPAN TERIMAKASIH}

Terima kasih disampaikan pada kepada ITB, UPI, Laboratorium Puslit Kimia LIPI PUSPITEK Serpong, Banten dan Bandung yang telah membantu pengukuran spektrum dan uji aktivitas, dan juga Herbarium Bogoriensis Bogor yang telah mengidentifikasi sampel tumbuhan yang digunakan dalam penelitian ini. Ucapan terimakasih juga disampaikan kepada Pusat Terpadu Basic Science Unpad atas bantuan dana penelitian.

\section{DAFTAR PUSTAKA}

Burkill, I.H. 1966. Tree Flora of Malaya, Manual for Foresters, Vol. $1(A-H)$. Malaysia, Kulalumpur: Ministry of Agriculture and Cooperatives.

Heyne, K. 1987. Tumbuhan Berguna Indonesia. Jilid III. Jakarta: Yayasan SaranaWana Jaya.

Mahabusarakum, W., Chairerk, P. \& Taylor, W.C.. 2005. Structure elucidation of xanthones from Garcinia cowa Roxb. Late, Phytochemistry: 66, 1148-1153.

Na Pattalung, P., Thongtheeraparp, W., Wiriyachitra , P. \& Taylor, W.C. 1994. Xanthones of Garcinia cowa. Planta Med. 60: 365-368.

Kanda Panthong, Wipapan Pongcharoen, souwalak Phongpaichir \& W.C. Taylor. 2006. Tetra oxygenated 
xanthones from the fruit of Garcinia cowa. Phytochemistry 67: 999-1004.

Justin Komguem , A.L. Meli, R.N. Manfouo, David Lontsi, F.N. Ngounou, V. Kuete, Hippolyte W. kamdem, Pirre Tane, Bonaventure T. Ngadjui, Beiben L. Sondengam \& Joseph D. Connolly. 2005. Xanthones from Garcinia smeathmannii (Oliver) and their antimicrobial activity, Phytochemistry 66: 1717-1773.

Panthong, K, Pongcharoen, W., Phongpaichit, W. \& Taylor, W.C. 2006. Tetraoxygenated Xanthones from The Fruit of Garcinia cowa. Phytochemistry 67: 999-1004.
Poomipamorn, S. \& Kumomg, A. 1997. Edible Multiporpuse ree Species Faung Fa. Bangkok: Printing (in Tai).

Skehan, P., Storeng, R., Scudiero, D., Monks, A., McMahon, J., Vistica, D., Warren, J.T., Bokesch, H., Kenney, S. \& Boyd, M.R. 1990. New Colorimetric Cytotoxicity Assay for Anticancer-Drug Screening. Journal of the National Cancer Insitute 82: 1107-1112.

Wahyuni, F.S., Lajis, N.H., Stanslas., J., Ali, D.A.I., Shaari, K. \& Dachriyanus. 2004. Isolation of bioactive compounds from Garcinia cowa Roxb. 14th Indonesian National Symposium on Natural Products Chemistry. Bandung,16$17^{\text {th }}$ December 2004. 